\title{
PERBANDINGAN REGRESI ROBUST PENDUGA MM DENGAN METODE RANDOM SAMPLE CONSENSUS DALAM MENANGANI PENCILAN
}

\author{
Ni Putu Nia Irfagutami ${ }^{1}$, I Gusti Ayu Made Srinadi ${ }^{2}$, I Wayan Sumarjaya ${ }^{3}$ \\ 1,2,3 Jurusan Matematika FMIPA Universitas Udayana, Bukit Jimbaran-Bali \\ e-mail: ${ }^{1} 1,{ }^{2}$ srinadiigustiayumade@yahoo.co.id, ${ }^{3}$ sumarjaya@unud.ac.id,
}

\begin{abstract}
The presence of outliers in observation can result in biased in parameter estimation using ordinary least square $(O L S)$. Robust regression MM-estimator is one of the estimations methods that able to obtain a robust estimator against outliers. Random sample consensus (ransac) is another method that can be used to construct a model for observations data and also estimating a robust estimator against outliers. Based on the study, ransac obtained model with less biased estimator than robust regression MM-estimator.
\end{abstract}

Keywords: Outlier, Robust Regression, MM-estimate, ransac

\section{Pendahuluan}

Model regresi dapat menggambarkan hubungan antarpeubah kuantitatif, sehingga satu atau lebih peubah dapat digambarkan oleh peubah lainnya. Model regresi linear sederhana, yakni $Y_{i}=\beta_{0}+\beta_{1} X_{i}+\varepsilon_{i}$ merupakan suatu model yang terdiri dari satu peubah bebas dan satu peubah respons. Parameter-parameter yang membentuk model selanjutnya diduga dengan menggunakan metode kuadrat terkecil (MKT).

Metode kuadrat terkecil merupakan metode pendugaan parameter yang dilakukan dengan meminimumkan jumlah simpangan kuadrat $Q=\sum_{i=1}^{n}\left(Y_{i}-\beta_{0}-\beta_{1} X_{i}\right)^{2}$. Asumsi kenormalan, kehomogenan ragam, dan tidak terjadi autokorelasi pada komponen sisaan atau galat merupakan syarat dalam penggunaan metode ini. Apabila asumsi ini terpenuhi maka penduga yang dihasilkan akan bersifat takbias. Namun, tidak jarang ditemukan kasus dengan asumsi kenormalan, kehomogenan ragam, dan tidak terjadi autokorelasi tidak terpenuhi. Salah satu penyebabnya adalah adanya pencilan dalam data amatan yang memengaruhi proses analisis. Salah satu alternatif yang dapat digunakan untuk mengatasi permasalah ini yakni dengan menerapkan metode regresi robust.

Regresi robust merupakan suatu metode yang dapat menghasilkan penduga parameter yang kekar terhadap pencilan. Metode ini tetap menggunakan keseluruhan data, termasuk data pencilan, namun dengan memberikan bobot yang kecil pada data pencilan. Metode lain yang dapat diterapkan yakni ransac diperkenalkan pertama kali oleh Fischler dan Bolles pada tahun 1981 sebagai suatu paradigma dalam pembentukan model untuk data eksperimen. Metode ini menggunakan sedikit mungkin himpunan data dan memperluas himpunan ini dengan sekumpulan data yang konsisten (Fischler dan Bolles, 1981). Perbandingan kedua metode yang samasama mampu menghasilkan penduga yang kekar terhadap pencilan merupakan fokus dalam penelitian ini. Ketidakbiasan penduga

\footnotetext{
${ }^{1}$ Mahasiswa Jurusan Matematika FMIPA Universitas Udayana

${ }^{2}$ Staf Pengajar Jurusan Matematika FMIPA Universitas Udayana
} 
yang dihasilkan oleh masing-masing metode akan menjadi acuan dalam penelitian ini.

\section{Metode Penelitian}

Data yang digunakan pada penelitian ini merupakan data simulasi dengan satu peubah bebas (X) dan satu peubah respons (Y). Data dibangkitkan dengan bantuan program $\mathrm{R}$ versi 2.15.3 Adapun tahapan yang dilakukan dalam penelitian ini, yakni (1) Pembangkitan data. Adapun pembangkitan data dilakukan dengan ketentuan, peubah bebas $(X)$ terdiri dari 100 amatan dengan nilai-nilai peubah $X$ adalah 1,2 , ..., 100. Nilai sisaan yang dibangkitkan merupakan data yang berdistribusi normal dengan rataan nol dan ragam satu sebanyak 100. Pembangkitan data pencilan, yang mana pada penelitian pencilan minor merupakan data yang berdistribusi normal dengan rataan lima dan standar deviasi 0,1 , sedangkan pencilan mayor merupakan data yang berdistribusi normal dengan rataan delapan dan standar deviasi 0,1 . Adapun pencilan yang dibangkitkan yakni sebesar 5\%, 10\%, 15\%, $20 \%$, 25\%, dan $30 \%$ dari data, baik pencilan minor maupun mayor. Penempatan pencilan pada bagian bawah, tengah dan bagian atas dari gugus data dilakukan untuk melihat pengaruh posisi pencilan terhadap proses analisis. Setelah terdapat data sisaan yang mengandung pencilan dan peubah bebas, maka dapat dibangkitkan data untuk peubah respon (Y). Ditentukan terlebih dahulu hubungan peubah bebas dan peubah respons yaitu $Y=\beta_{0}+\beta_{1} X+\varepsilon$ \}.

Pada penelitian ini ditetapkan nilai $\beta_{0}=2$ dan $\beta_{1}=3$. Berdasarkan nilai peubah bebas, koefisien regresi, dan nilai sisaan yang mengandung pencilan, maka akan didapat 36 kelompok data peubah respons yang mengandung pencilan. (2) Melakukan uji Anderson-Darling untuk melihat kenormalan data. (3) Melakukan analisis data dengan regresi robust penduga MM dan (4) random sample consensus untuk setiap data yang dimiliki. (5) Membandingkan penduga parameter yang dihasilkan oleh metode regresi robust penduga MM dan ransac untuk melihat metode manakah yang menghasilkan penduga parameter yang lebih baik.

\section{Hasil dan Pembahasan}

Setelah dibangkitkan data peubah bebas, data sisaan, dan data peubah respon baik dengan pencilan maupun tanpa pencilan, maka dilakukan pendugaan parameter dengan menggunakan metode kuadrat terkecil. Terdapat dua asumsi yang harus dipenuhi dalam menggunakan metode ini, yakni data yang digunakan menyebar normal dan memiliki ragam yang homogen. Apabila kedua asumsi ini terpenuhi maka penduga yang dihasilkan akan bersifat takbias.

Metode kuadrat terkecil merupakan suatu metode pendugaan parameter dengan meminimumkan jumlah kuadrat galat. Jumlah kuadrat galat dapat dituliskan sebagai berikut:

$$
\begin{aligned}
S\left(\beta_{j}\right) & =\sum_{i=1}^{n} \varepsilon_{i}^{2} \\
& =\sum_{i=1}^{n}\left(Y_{i}-\beta_{0}-\beta_{1} X_{i}\right)^{2},
\end{aligned}
$$

Untuk meminimumkan jumlah kuadrat galat maka persamaan (1) akan diturunkan secara kalkulus terhadap parameter $\beta_{0}$ dan $\beta_{1}$. Kedua persamaan turunan tersebut selanjutnya disamakan dengan nol. Dengan demikian diperoleh nilai-nilai penduga parameter sebagai berikut,

$$
\begin{aligned}
b_{0} & =\frac{\sum_{i=1}^{n} Y_{i}}{n}-b_{1} \frac{\sum_{i=1}^{n} X_{i}}{n}, \\
b_{1} & =\frac{\sum_{i=1}^{n}\left(X_{i}-\bar{X}\right)\left(Y_{i}-\bar{Y}\right)}{\sum_{i=1}^{n}\left(X_{i}-\bar{X}\right)^{2}} .
\end{aligned}
$$

Setelah dilakukan analisis pada masing-masing kelompok data yang mengandung pencilan dengan menggunakan metode kuadrat terkecil, maka dihitung nilai sisaan untuk masingmasing model. Nilai sisaan ini selanjutnya digunakan untuk melakukan pengujian asumsi kenormalan dengan menggunakan uji Anderson-Darling. 
Uji Anderson-Darling melibatkan fungsi distribusi kumulatif dari sebaran data. Misalkan data yang akan diuji diasumsikan berdistribusi normal dengan tingkat signifikan $\alpha$, maka statistik uji yang digunakan adalah $A^{2}=-n-S$, dengan

$S=\frac{1}{n} \sum_{i=1}^{n}[2 i-1]\left[\ln \left(F\left(Z_{i}\right)\right)+\ln \left(1-F\left(Z_{n+1-i}\right)\right)\right]$, dengan

$$
Z_{i}=\frac{x_{i}-\bar{x}}{s} .
$$

Adapun hipotesis yang diuji yakni:

$\mathrm{H}_{0}$ : data mengikuti sebaran normal

$\mathrm{H}_{1}$ : data tidak mengikuti sebaran normal, dengan kaidah keputusannya yakni jika $A^{2}$ lebih besar dari nilai kritis uji AndersonDarling maka tolak $\mathrm{H}_{0}$ dan jika $A^{2}$ lebih kecil dari nilai kritis uji Anderson-Darling maka $\mathrm{H}_{0}$ gagal ditolak. Apabila nilai $p$-value lebih kecil dari $\alpha$ maka tolak $\mathrm{H}_{0}$, apabila sebaliknya, terima $\mathrm{H}_{0}$.

Berdasarkan hasil uji Anderson-Darling pada data sisaan untuk masing-masing model yang diduga dengan metode kuadrat terkecil, didapat bahwa semua data yang diberikan pencilan, baik pencilan minor maupun mayor dengan persentase $5 \%, 10 \%, 15 \%, 20 \%, 25 \%$, dan $30 \%$ pada bagian bawah, tengah, dan atas, memiliki $p$-value yang lebih kecil dari nilai alfa yang ditentukan, yakni $\alpha=0,05$. Hal ini berarti bahwa semua data yang mengandung pencilan tidak memenuhi asumsi kenormalan atau dapat dikatakan data tidak menyebar normal. Sehingga akan diterapkan metode regresi robust penduga MM dan metode ransac dalam analisis.

Regresi robust merupakan salah satu metode regresi yang mampu menghasilkan penduga parameter yang robust (kekar) terhadap pencilan. Metode ini bekerja dengan memberikan bobot pada pencilan yang kemudian membatasi pengaruh pencilan tersebut. Penduga MM merupakan salah satu metode estimasi yang diperkenalkan pertama kali oleh Yohai (1987) sebagai metode yang menggabungkan metode penduga M (Maximum
Likelihood) dan penduga S (Scale). Regresi robust dengan penduga $S$ akan menjamin penduga parameter memiliki nilai breakdown point yang tinggi dan regresi robust dengan penduga $\mathrm{M}$ akan menjamin penduga parameter memiliki efisiensi yang tinggi. Hal inilah yang menyebabkan metode regresi robust penduga MM memiliki tingkat efisiensi dan breakdown point yang tinggi.

Pendugaan parameter dengan metode penduga MM dilakukan dengan dua tahap. Pertama, pendugaan parameter regresi awal yang diawali dengan menghitung nilai penduga skala menggunakan metode penduga S. Kedua, menaksir penduga parameter regresi akhir dengan menggunakan metode penduga $\mathrm{M}$. Adapun langkah-langkah pendugaan parameter dengan menggunakan metode penduga MM, yakni, (1) Menghitung nilai awal penduga parameter $\widehat{\boldsymbol{b}}$ dengan menggunakan penduga $\mathrm{S}$ (high breakdown point), yang mana penduga awal yang dihasilkan tidak harus efisien. Kemudian gunakan penduga ini untuk menghitung residual,

$\varepsilon_{i_{2} 0}=\boldsymbol{y}-\boldsymbol{x}^{T} \widehat{\boldsymbol{b}}$. (2) Dari nilai residual pada langkah pertama, dihitung penduga skala, $s_{n}=s\left(\varepsilon_{1}(\beta), \varepsilon_{2}(\beta), \cdots, \varepsilon_{n}(\beta)\right) \quad$ yang didefinisikan sebagai solusi dari

$\frac{1}{n} \sum_{i=1}^{n} \rho_{0}\left(\frac{\varepsilon_{i, 0}}{s_{n}}\right)=\delta$

dengan $\delta$ merupakan konstanta yang memenuhi $\delta=E(\phi, \rho(\infty)), \quad \phi$ berdistribusi normal standar dan $\rho(u)$ merupakan fungsi objektif yang menurut (Rousseeuw dan Leroy, 1987) harus memenuhi, (i) $\rho$ merupakan fungsi simetris dan terdiferensialkan secara kontinu, dan $\rho(0)=0$, (ii) jika terdapat $a>0$, maka $\rho$ akan meningkat pada $[0, a]$ dan konstan pada $[a, \infty)$, (iii) $\frac{K}{\rho(a)}=\frac{1}{2}$. Fungsi objektif yang digunakan pada langkah ini adalah fungsi objektif Tukey Bisquare, 


$$
\begin{gathered}
\rho(u)=\left\{\begin{array}{l}
\frac{c^{2}}{6}\left(1-\left(1-\left(\frac{u}{c}\right)^{2}\right)^{3}\right) ;|u| \leq c \\
\frac{c^{2}}{6} ;|u|>c
\end{array}\right. \\
\text { dengan } c=1,56[3] .
\end{gathered}
$$

(3) Setelah mendapatkan nilai sisaan $\varepsilon_{i, 0}$ dan penduga skala $s_{n}$, hitung pembobot awal $\left(w_{i, 0}\right)$ sesuai dengan fungsi pembobot Tukey Bisquare,

$$
w_{i, 0}\left(\varepsilon_{i}^{*}\right)=\left\{\begin{array}{r}
\left(1-\left(\frac{\varepsilon_{i}^{*}}{c}\right)^{2}\right)^{2} ;|u| \leq c \\
0|u|>c
\end{array}\right.
$$

dengan $\varepsilon_{i_{2}, 0}{ }^{*}=\frac{\varepsilon_{i, 0}}{s_{n}}$ dan $c=4,68$ (Yohai, 1987). Kemudian dihitung nilai penduga MM sebagai:

$$
\boldsymbol{b}_{l}=\left(\boldsymbol{X}^{T} \boldsymbol{W}_{l-1} \boldsymbol{X}\right)^{-1} \boldsymbol{X}^{T} \boldsymbol{W}_{l-1} \boldsymbol{Y}
$$

dengan $\boldsymbol{W}_{l-1}$ merupakan matriks diagonal yang elemen diagonalnya adalah nilai dari fungsi pembobot $w_{i, l-1}$ dengan $l$ menyatakan iterasi. (4) Hitung nilai $\sum_{i=1}^{n}\left|\varepsilon_{i, 1}\right|$, dengan $\varepsilon_{i, 1}=\boldsymbol{y}-\boldsymbol{x}^{T} \boldsymbol{b}_{\boldsymbol{l}}$. (5) Ulangi langkah kedua hingga empat. Iterasi dihentikan ketika telah mendapatkan nilai $\sum_{i=1}^{n}\left|\varepsilon_{i, 1}\right|$ yang konvergen.

Setelah didapat penduga parameter dengan menggunakan metode regresi robust penduga MM, maka dicari selang kepercayaan masing-masing penduganya. Selang kepercayaan digunakan untuk melihat sifat ketakbiasan penduga yang dihasilkan. Apabila selang kepercayaan mencakup nilai parameter yang sebenarnya, maka penduga parameter yang dihasilkan memiliki sifat takbias. Berdasarkan selang kepercayaan 95\% diperoleh bahwa metode regresi robust menghasilkan penduga intercept $\left(\beta_{0}\right)$ yang berbias saat terdapat pencilan minor sebesar $10 \%, 15 \%$, $20 \%, 25 \%$, dan $30 \%$ pada bagian bawah gugus data, pencilan minor sebesar $30 \%$ pada bagian tengah gugus data, pencilan minor sebesar $20 \%$, 25\% dan $30 \%$ pada bagian atas gugus data, dan saat terdapat pencilan mayor sebesar $30 \%$ pada bagian bawah gugus data.

Metode ini juga menghasilkan penduga slope $\left(\beta_{1}\right)$ yang berbias saat terdapat pencilan minor sebesar 10\%, 15\%, 20\%, 25\%, dan 30\% pada bagian bawah gugus data, pencilan minor sebesar $15 \%, 20 \%, 25 \%$, dan $30 \%$ pada bagian atas gugus data, dan saat terdapat pencilan mayor sebesar $30 \%$ pada bagian bawah gugus data. Untuk jenis data pencilan lainnya, metode regresi robust penduga MM menghasilkan penduga yang takbias. Hal ini lebih jelasnya dapat dilihat pada Tabel 1. 
Tabel 1 Selang Kepercayaan 95\% $\beta_{0}$ dan $\beta_{1}$ dengan Metode Regresi Robust Penduga MM

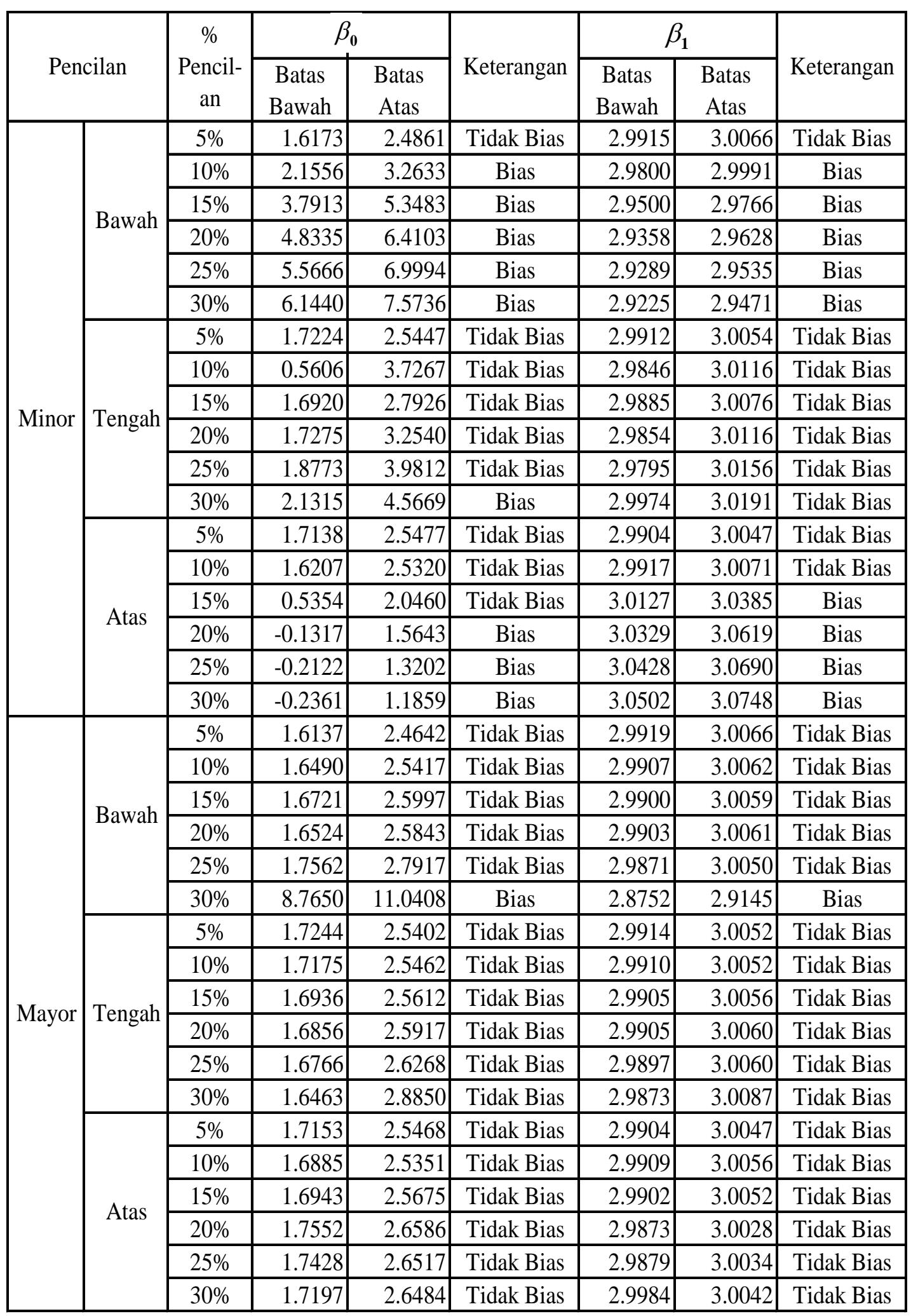


Kemudian metode lain yang dapat digunakan untuk mendapat penduga yang kekar terhadap pencilan yakni metode ransac. Ransac diperkenalkan pertama kali oleh Fischler dan Bolles (1981) sebagai suatu metode pembentukan model bagi data eksperimen. Proses pembentukan model terbaik dengan menggunakan metode ini sangatlah berbeda dengan metode regresi robust. Apabila regresi robust menggunakan seluruh data dalam pendugaan parameter, maka random sample consensus menggunakan seminimum mungkin data untuk membentuk model yang mampu menjelaskan keseluruhan data ( Fischler dan Bolles, 1981).

Adapun proses pembentukan model dengan menggunakan metode ransac (3), yakni (1) dipilih 2 data secara acak dari sekumpulan 100 data. Selanjutnya kumpulan 2 data ini disebut sebagai himpunan $S_{1}$. (2) Bentuk model dengan menggunakan 2 data tersebut, sebut $M_{1}$. Pembentukan model dapat dilakukan dengan metode kuadrat terkecil (least square). (3) Berdasarkan model $M_{1}$, bentuk himpunan baru $\left(S_{1}^{*}\right)$ dari keseluruhan data yang mana anggota himpunannya merupakan data yang memiliki sisaan dalam toleransi error $(t)$. Himpunan ini selanjutnya disebut sebagai consensus set $S_{1}$. (4) Jika $\left(S_{1}^{*}\right)$ lebih besar dari batasan (threshold), $T$, maka gunakan $S_{1}{ }^{*}$ untuk membentuk model baru, yakni $M_{1}^{*}$. (5) Jika $\left(S_{1}^{*}\right)$ lebih kecil dari batasan (threshold), T, maka pilih secara acak himpunan baru $S_{2}$ dan ulangi langkah (2).

Setelah didapatkan penduga parameter dengan menggunakan metode ransac, maka dicari selang kepercayaan masing-masing penduganya. Berdasarkan selang kepercayaan 95\% diketahui bahwa metode ransac menghasilkan penduga parameter $\beta_{0}$ yang berbias saat terdapat pencilan minor pada bagian bawah gugus data sebesar $25 \%$ dan
$30 \%$, dan pada bagian tengah gugus data sebesar 25\% dan 30\%. Ransac juga menghasilkan penduga parameter $\beta_{1}$ yang berbias saat terdapat pencilan minor pada bagian bawah gugus data sebesar $25 \%$ dan $30 \%$ dan juga saat terdapat pencilan minor sebesar $25 \%$ dan $30 \%$ pada bagian atas gugus data. Untuk jenis data lainnya, ransac menghasilkan penduga parameter yang bersifat takbias. Hal ini lebih jelasnya dapat dilihat pada Tabel 2. 
Tabel 2 Selang Kepercayaan $95 \% \beta_{0}$ dan $\beta_{1}$ dengan Metode Ransac

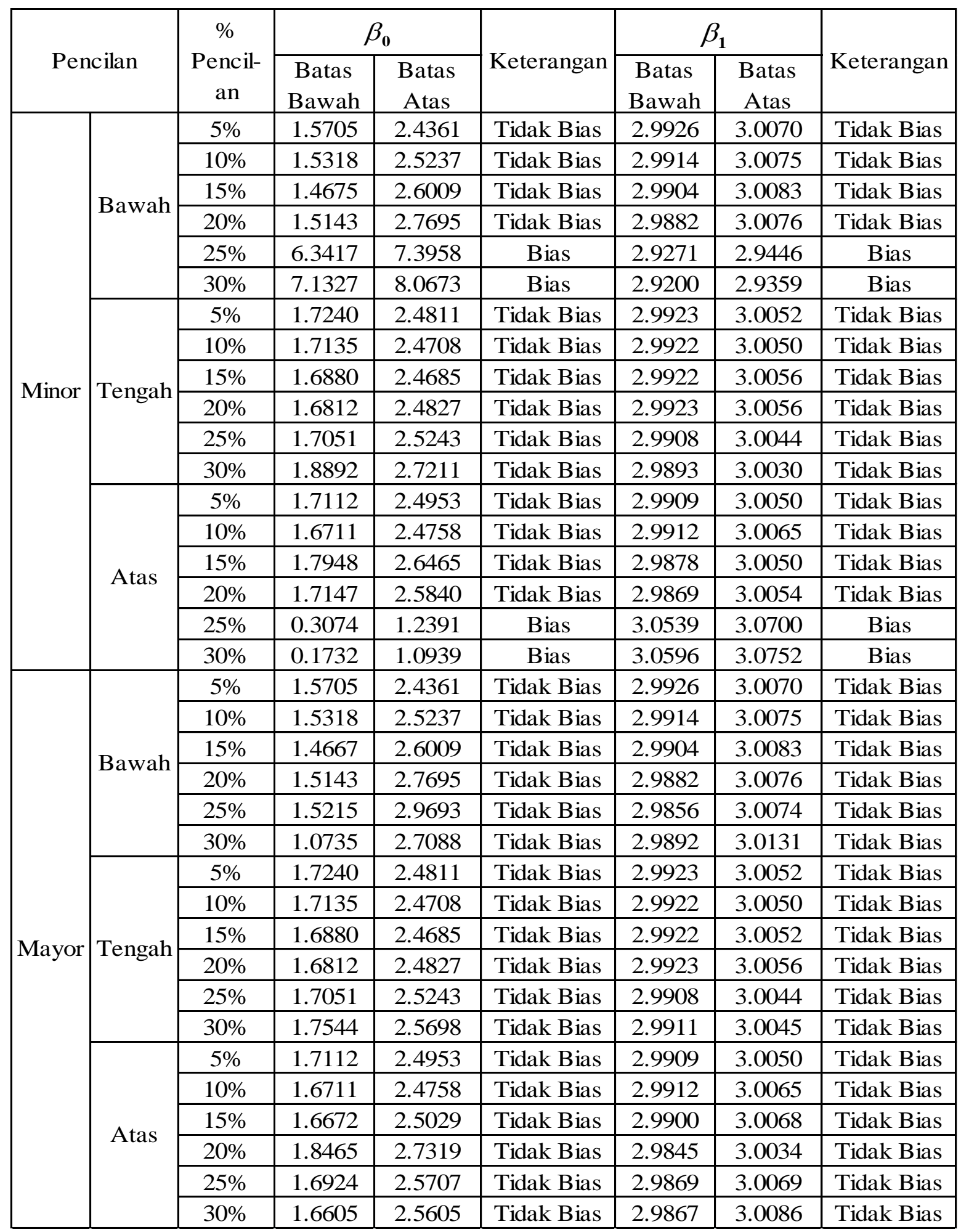




\section{Kesimpulan}

Adanya pencilan pada bagian ujung gugus data memengaruhi proses pendugaan parameter. Hal ini dilihat dari penduga yang dihasilkan oleh metode regresi robust penduga MM bersifat bias saat terdapat pencilan minor sebesar 10\% hingga 30\% pada bagian bawah gugus data, pencilan minor sebesar $15 \%$ hingga $30 \%$ pada bagian atas gugus data, dan pada saat terdapat pencilan mayor sebesar $30 \%$ pada bagian bawah gugus data. Sedangkan, metode ransac menghasilkan penduga yang berbias saat terdapat pencilan minor sebesar $25 \%$ hingga $30 \%$ baik pada bagian bawah gugus data maupun bagian atas gugus data

Dapat dilihat pula metode ransac menghasilkan lebih sedikit model yang mengandung penduga parameter berbias dibandingkan dengan metode regresi robust penduga MM. Dari 36 model yang dihasilkan oleh kedua metode, ransac hanya menghasilkan empat model yang mengandung penduga parameter berbias. Sedangkan dengan metode regresi robust penduga MM, terdapat 11 model yang mengandung penduga parameter berbias.

\section{Daftar Pustaka}

Martin A. Fischler and Robert C. Bolles, "Random Sample Consensus: A Paradigm for Model Fitting with Application to Image Analysis and Automated Cartography," Graphics and Image Processing, vol. 24, no. 6, pp. 381-395, June 1981.

Peter J. Rousseeuw and Annick M. Leroy, Robust Regression and Outlier Detection. Canada: John Wiley \& Sons, Inc., 1987.

Victor J. Yohai, "High Breakdown-Point and High Effiency Robust Estimats for Regression," The Annals of Statistics, vol. 15, no. 2, pp. 642-656, Jun 1987. 